\title{
Identifikasi Bakteri dan Sensitivitas Terhadap Antibiotik Pada Otitis Media Supuratif Kronis Di RSUP Dr. M. Djamil Padang
}

\author{
Bahana Sasmita1 , Rismawati Yaswir², H.Lillah²
}

\begin{abstract}
Abstrak
Otitis Media Supuratif Kronis (OMSK) didefinisikan infeksi telinga tengah yang ditandai oleh sekret terusmenerus atau berulang selama tiga bulan atau lebih melalui perforasi membran timpani. Uji sensitivitas penting untuk perencanaan terapi, mengurangi potensi risiko komplikasi dan mencegah resistensi. Tujuan: Mengetahui hasil identifikasi dan sensitivitas terhadap antibiotik pada penderita Otitis Media Supuratif Kronis. Metode: Penelitian deskriptif retrospektif ini dilakukan di Laboratorium Sentral RSUP Dr M Djamil Padang dari bulan Januari 2016 sampai dengan Juni 2016. Hasil: Bakteri terbanyak penyebab Otitis Media Supuratif Kronis pada spesimen swab telinga adalah Stafiloccocus sp (37,73\%) yang sensitif terhadap Meropenem (50\%) dan resisten terhadap Ampicillin (100\%), Amoxicillin (95\%), Ciprofloxacin (95\%) dan Levofloxacin (95\%). Bakteri penyebab terbanyak kedua adalah Pseudomonas sp (26,41\%) yang sensitif terhadap Meropenem (92,85\%) dan resisten terhadap Ampicillin (100\%), Amoxicillin (100\%), Chloramfenicol (100\%), Erytromycin (100\%), dan Sulfamethoxazole Trimethoprim (100\%). Simpulan: Bakteri terbanyak penyebab Otitis Media Supuratif Kronis pada spesimen swab telinga adalah Staphylococcus sp (37,73\%) yang sensitif terhadap Meropenem (50\%) dan Pseudomonas sp (26,41\%) yang sensitif terhadap Meropenem (92,85\%)
\end{abstract}

Kata kunci: otitis media supuratif kronis, uji sensitivitas, antibiotik

\begin{abstract}
Chronic Suppurative Otitis Media (CSOM) is defined as a middle ear infection characterized by persistent or recurrent secretions for three or more months through tympanic membrane perforation. Sensitivity tests are important for therapeutic planning, reducing the potential risk of complications and preventing resistance. Objectives: To found out the results of identification and sensitivity to antibiotics in patients with Chronic Suppurative Otitis Media. Methods: This was a retrospective descriptive study that was conducted at the Central Laboratory of Dr M Djamil Hospital Padang from January 2016 to June 2016. Results: The most bacteria caused Chronic Suppurative Otitis Media of the ear swab specimens was Staphylococcus sp (37.73\%) were sensitive to Meropenem (50\%) and resistant to Ampicillin (100\%), Amoxicillin (95\%), Ciprofloxacin (95\%) and Levofloxacin (95\%). The second most common cause of bacteria are Pseudomonas sp (26.41\%) were sensitive to Meropenem (92.85\%) and resistant to Ampicillin (100\%), Amoxicillin (100\%), Chloramfenicol (100\%), Erythromycin (100\%), and Sulfamethoxazole Trimethoprim (100\%). Conclusion: The most bacteria that cause Chronic Suppurative Otitis Media in-ear swab specimens are Staphylococcus sp (37.73\%) which are sensitive to Meropenem (50\%) and Pseudomonas sp (26.41\%) which are sensitive to Meropenem (92.85\%) Keywords: chronic suppurative otitis media, sensitivity test, antibiotics

Affiliasi penulis: 1. Program Pendidikan Dokter Spesialis Patologi Klinik Fakultas Kedokteran Universitas Andalas Padang (FK Unand), 2, Bagian Patologi Klinik FK Unand

Korespondensi: Rismawati Yaswir,Telp: 081267125282

\section{PENDAHULUAN}

Otitis Media Supuratif Kronis (OMSK) didefinisikan infeksi telinga tengah yang ditandai oleh sekret terus-menerus atau berulang selama tiga bulan
\end{abstract}


atau lebih melalui perforasi membran timpani. ${ }^{1,2}$ Otitis Media Supuratif Kronis sering mengenai anak-anak dan bayi. ${ }^{3,4}$ Sekret pada OMSK berwarna putih keabuabuan, keruh, dan kental. ${ }^{5}$ Komplikasi OMSK dapat mengenai kranial dan intrakranial.6,7 Komplikasi biasanya terjadi pada jenis OMSK maligna, yang disertai dengan pembentukan kolesteatoma. Infeksi dapat menyebar dari telinga tengah ke struktur yang berdekatan melalui beberapa cara, seperti hematogen, erosi tulang, atau fraktur tengkorak. ${ }^{8}$

Prevalensi OMSK di Indonesia secara umum adalah 3,9\%, sedangkan di Bagian Telinga Hidung Tenggorok Bedah Kepala dan Leher (THT-KL) RSUP Dr M Djamil Padang periode Januari 2010 sampai Desember 2012 didapatkan 704 kasus OMSK tipe aman dan 82 kasus OMSK tipe bahaya. ${ }^{9}$

Mikroorganisme penyebab OMSK terbanyak adalah Pseudomonas aeruginosa dan Staphylococcus aureus diikuti oleh Proteus vulgaris dan Klebsiella pneumonia. ${ }^{10,11}$ Pemberian antibiotik yang inadekuat dan kondisi kebersihan yang buruk berhubungan dengan perkembangan OMSK. ${ }^{12,13}$ Uji sensitivitas penting untuk perencanaan terapi, mengurangi potensi risiko komplikasi dan mencegah resistensi. ${ }^{14,15}$

\section{METODE}

Penelitian ini merupakan penelitian deskriptif retrospektif yang dilakukan di Instalasi Laboratorium Sentral RSUP Dr M Djamil Padang Januari-Juni 2016. Sampel penelitian adalah kultur positif dari spesimen swab telinga dengan diagnosis Otitis Media Supuratif Kronis.

Uji sensitivitas antibiotik dilakukan dengan metode Kirby-Bauer yang sesuai dengan Clinical and Laboratory Standards Institute (CLSI).

\section{HASIL}

Telah dilakukan penelitian terhadap 53 spesimen swab telinga penderita otitis media supuratif kronis yang diperiksa di Instalasi Laboratorium Sentral RSUP Dr M Djamil Padang selama periode JanuariJuni 2016. Bakteri-bakteri yang ditemukan adalah Staphylococcus sp sebanyak $37,73 \%$, Pseudomonas sp sebanyak 26,41\%, Klebsiella sp $18,86 \%$, Proteus sp 11,32\%, dan Acinetobacter sp 5,66\% (Gambar 1).

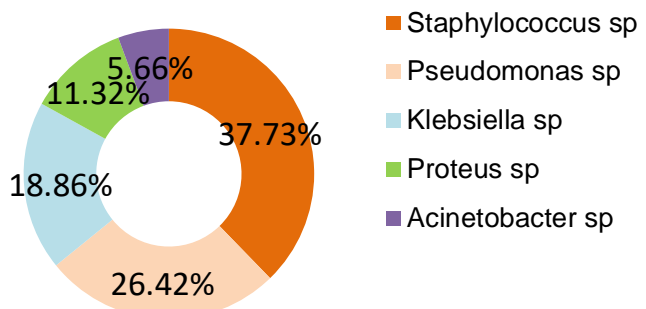

Gambar 1. Hasil kultur swab telinga penderita otitis media supuratif kronis di Instalasi Laboratorium Sentral RSUP Dr. M. Djamil Padang periode JanuariJuni 2016.

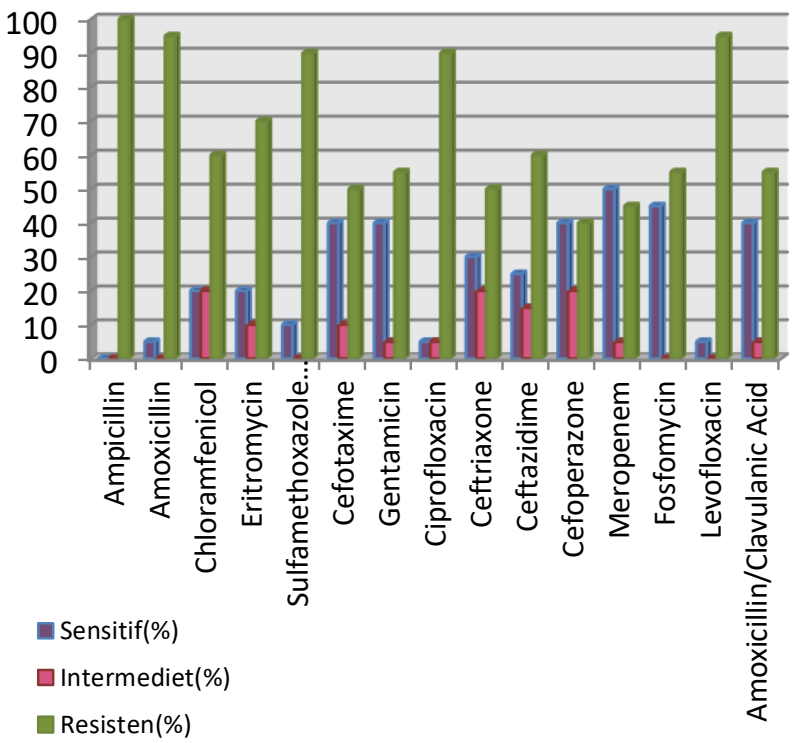

Gambar 2. Hasil uji sensitivitas Staphylococcus sp terhadap beberapa Antibiotik

Pada Gambar 2, terlihat hasil uji sensitivitas antibiotik terhadap Staphylococcus sp pada spesimen swab telinga penderita otitis media supuratif kronis ditemukan bahwa kuman ini telah resisten, tetapi beberapa masih sensitif terhadap Meropenem (50\%), Fosfomycin (45\%) kemudian Cefotaxime (40\%) dan Gentamycin (40\%), Cefoperazone (40\%), dan Amoxicillin/Clavulanic Acid (40\%). Resistensi kuman ini tertinggi terhadap Ampicillin (100\%), Amoxicillin (95\%), Ciprofloxacin (95\%) dan Levofloxacin (95\%). 


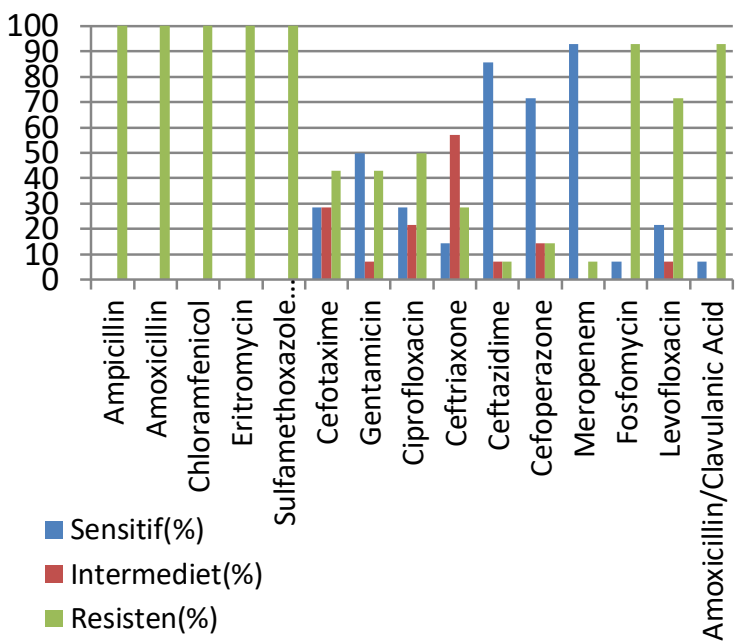

Gambar 3. Hasil uji sensitivitas Pseudomonas sp terhadap beberapa antibiotik

Pada Gambar 3, didapatkan hasil uji sensitivitas antibiotik terhadap Pseudomonas sp pada spesimen swab telinga pada penderita Otitis Media Supuratif Kronis di Instalasi Laboratorium Sentral RSUP Dr M Djamil Padang selama periode JanuariJuni 2016 ditemukan bahwa Pseudomonas sp sensitif terhadap Meropenem (92,85\%), Ceftazidime $(85,71 \%)$. Resistensi kuman ini ditemukan terhadap Ampicillin (100\%), Amoxcicillin (100\%), Chloramfenicol $(100 \%)$, Erytromycin $(100 \%)$, dan Sulfamethoxazole Trimethoprim (100\%).

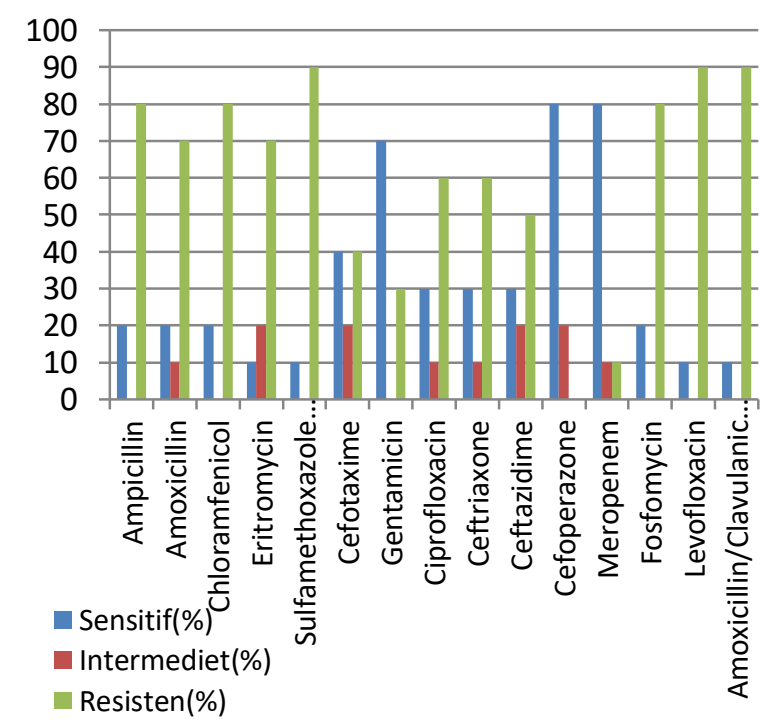

Gambar 4. Hasil uji sensitivitas Klebsiella $s p$ terhadap beberapa antibiotik
Pada Gambar 4, didapatkan hasil uji sensitivitas antibiotik terhadap Klebsiella $s p$ pada spesimen swab telinga pada penderita otitis media supuratif kronis di Instalasi Laboratorium Sentral RSUP Dr M Djamil Padang selama periode JanuariJuni 2016 ditemukan kuman ini memiliki resistensi yang tinggi terhadap antibiotik, yaitu Sulfamethoxazole Trimethoprim (90\%), Levofloxacin (90\%), dan Amoxcicillin/Clavulanic Acid (90\%). Sedangkan antibiotik dengan sensitivitas yang baik didapatkan pada Cefoperazone dan Meropenem yaitu masingmasing $80 \%$.

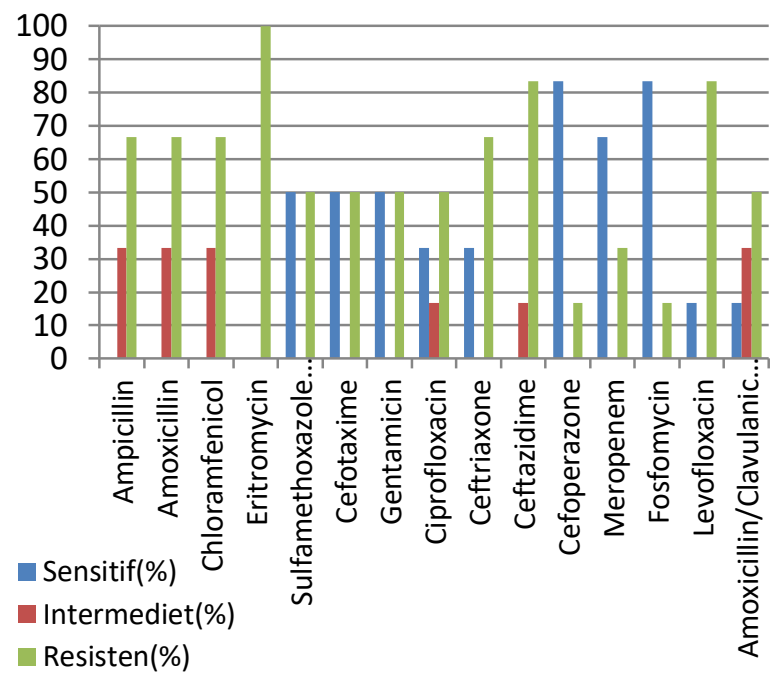

Gambar 5. Hasil uji sensitivitas Proteus sp terhadap beberapa antibiotik

Pada Gambar 5 didapatkan hasil uji sensitivitas antibiotik terhadap Proteus sp pada spesimen swab telinga pada penderita otitis media supuratif kronis di Instalasi Laboratorium Sentral RSUP Dr M Djamil Padang selama periode Januari-Juni 2016 ditemukan resistensi 100\% terhadap Erytromycin, kemudian Ceftazidime dan Levofloxacin masing-masing 83,33\%. Kuman ini masih memiliki sensitivitas yang cukup baik terhadap Cefoperazone dan Fosfomycin yaitu masingmasing $83,33 \%$. 


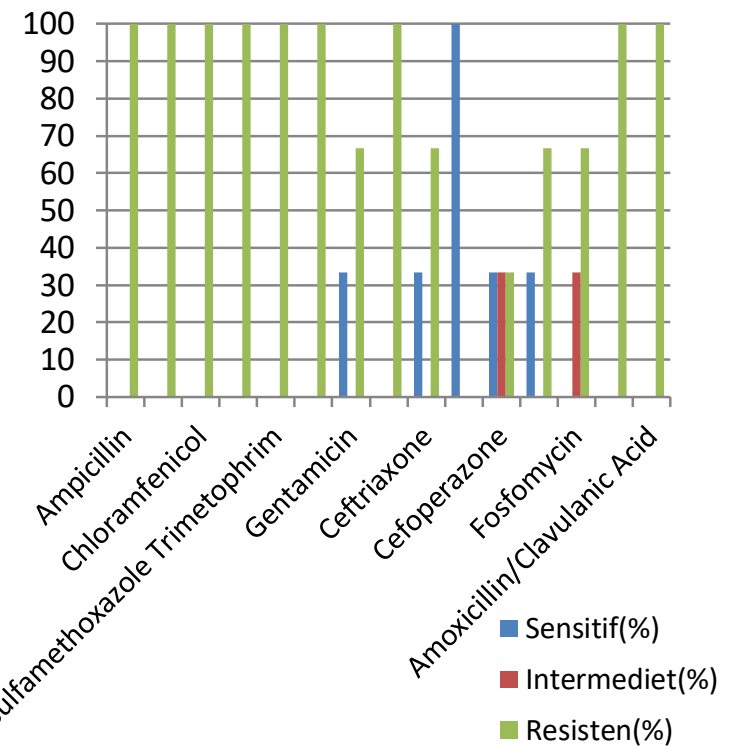

Gambar 6. Hasil uji sensitivitas Acinetobacter sp terhadap beberapa antibiotik

Pada Gambar 6 didapatkan hasil uji sensitivitas antibiotik terhadap Acinetobacter sp pada spesimen swab telinga pada penderita otitis media supuratif kronis di Instalasi Laboratorium Sentral RSUP Dr M Djamil Padang selama periode Januari - Juni 2016 ditemukan resistensi $100 \%$ pada sebagian besar antibiotik yaitu Ampicillin, Amoxcicillin, Chloramfenicol, Erytromycin, SulfamethoxazoleTrimethoprim, Cefotaxime, Ciprofloxacin, Levofloxacin dan Amoxcicillin/Clavulanic Acid. Pada uji sensitivitas ini ditemukan juga sensitivitas Ceftazidime yang sangat baik yaitu $100 \%$.

Hasil uji sensitivitas antibiotik terhadap Staphylococcus sp ditemukan resistensi yang tinggi pada Ampicillin (100\%), Amoxicillin (95\%), Ciprofloxacin (95\%) dan Levofloxacin (95\%) sedangkan sensitivitas yang tertinggi ditemukan terhadap Meropenem (50\%).

\section{PEMBAHASAN}

Pada penelitian ini ditemukan bakteri penyebab Otitis Media Supuratif Kronis yang terbanyak adalah Staphylococcus sp sebesar 37,73\% dan Pseudomonas sp. sebesar 26,41\%. Bakteri penyebab lainnya ialah Klebsiella $s p$, Proteus $s p$, dan Acinetobacter sp. Penelitian yang dilakukan oleh Nazir A dan Kadri tahun 2014 di India juga menemukan hasil yang hampir sama dengan penelitian ini yaitu bakteri penyebab Otitis Media Supuratif Kronis yang terbanyak adalah Pseudomonas sp (38,23\%) dan Staphylococcus sp (35,29\%). ${ }^{16}$

Penelitian yang dilakukan oleh Al-Hilli tahun 2015 di Irak didapatkan bakteri penyebab OMSK adalah Pseudomonas aeruginosa sebanyak (37,50\%), diikuti oleh Staphylococcus aureus (20,83\%), Streptococcus pneumoniae (16,67\%), Proteus $s p$ $(10,83 \%)$, Klebsiella sp $(8,33 \%)$, E.coli $(5,83 \%) .{ }^{17}$ Penelitian yang dilakukan oleh Ahmad tahun 2013 di didapatkan bakteri penyebab OMSK terbanyak adalah Staphylococcus aureus (45,1\%) dan Pseudomonas aeruginosa $(19,5 \%){ }^{18}$

Uji sensitivitas antibiotik terhadap Pseudomonas sp ditemukan tingkat sensitivitas yang tinggi terhadap Meropenem yaitu 92,85\% Hasil ini hampir sama dengan penelitian yang dilakukan Poorey dan Thakur tahun 2015 yang mendapatkan sensitivitas terhadap Meropenem sebesar 97,91\%.19 Ampicilin, Amoxcicillin, Chloramphenicol, Erytromycin dan Sulfamethoxazole-Trimetoprim memberikan resistensi yang tertinggi (100\%). Hasil ini sama dengan penelitian yang dilakukan oleh Wasihun dan Zemene di Ethiopia tahun 2015 yaitu Ampicillin dan Sulfamethoxazole-Trimetoprim resisten 100\%. ${ }^{20}$

\section{SIMPULAN}

Bakteri penyebab OMSK terbanyak yang ditemukan pada swab telinga penderita Otitis Media Supuratif Kronis di Instalasi Laboratorium Sentral RSUP Dr M Djamil Padang selama periode JanuariJuni 2016 adalah Staphylococcus sp dan Pseudomonas sp, dan masih sensitif terhadap Meropenem dan resistensi yang tertinggi adalah terhadap Ampicillin, Amoxicillin, SulfamethoxazoleTrimetoprim.

\section{SARAN}

Penelitian lebih lanjut perlu dilakukan tentang bakteri penyebab dan uji sensitivitas terhadap Otitis Media Supuratif Kronis.

\section{UCAPAN TERIMA KASIH}

Terima kasih kepada semua pihak yang telah membantu dalam penelitian ini. 


\section{DAFTAR PUSTAKA}

1. Kumar R, Agarwal RK, Gupta S. A microbiological study of chronic suppurative otitis media. International Journal of Recent Scientific Research. 2015; 6(7):5487-90.

2. Chavan A, Nagarkar R, Chavan GN, Deshmukh PT. A study of microbiological spectrum with its antibiotic susceptibility in patients of chronic suppurrative otitis media at RIMS, Adilabad. International Journal of Healthcare and Biomedical Research. 2014;3(1):152-7.

3. Shyamala R, Reddy PS. The study of bacteriological agents of chronic suppurative otitis media - aerobic culture and evaluation. Journal of Microbiology and Biotechnology Research. 2012; 2(1):152-62.

4. Muftah S, Mackenzie I, Faragher B, Brabin B. Prevalence of chronic suppurative otitis media (CSOM) and associated hearing impairment among school-aged children in Yemen. Oman Medical Journal. 2015;30(5):358-65.

5. Nia KM, Sepehri G, Khatmi H, Shakibaie MR. Isolation and antimicrobial susceptibility of bacteria from chronic suppurative otitis media patients in Kerman, Iran. Iranian Red Crescent Medical Journal. 2011;13(12):891-4.

6. Vishwanath S, Mukhopadhyay C. Chronic suppurative otitis media: optimizing initial antibiotic. Indian Journal Otolaryngol Head Neck Surg. 2012; 64(3):285-9.

7. Sharma N, Jaiswal AA. Complications of chronic suppurative otitis media and their management: a single institution 12 years experience. Indian Journal Otolaryngol Head Neck Surg. 2015; 67(4):353-60.

8. Desbassarie FW, Dermawan A, Hadi S. Profile of patients with complicated chronic suppurative otitis media in Dr Hasan Sadikin general hospital Bandung, Indonesia, January-December 2011. Althea Medical Journal. Indonesia 2015; 2 (1): 108-13.

9. Edward $Y$, Novianti D. Biofilm pada otitis media supuratif. Jurnal Kedokteran dan Kesehatan Jambi Medical Journal. 2015;3(1):68-78.

10. Saranya SK, Vazhavandal G, Ganesh V, Ismail M, Uma A, Subramaniam PT. Bacteriological and mycological profile of chronic suppurative otitis media in a tertiary teaching hospital, Trichy, Tamilnadu. International Journal of Pharmaceutical Science Invention. 2015;4(1):13-9.

11. Prakash M, Lakshmi K, Anuradha S, Swathi GN. Bacteriological profile and their antibiotic susceptibility pattern of cases of chronic suppurative otitis media. Asian Journal Pharm Clin Res. 2013;6(3):210-2.

12. Singh $A H$, Basu $R$, Venkatesh A. Aerobic bacteriology of chronic suppurative otitis media in Rajahmundry, Andhra Pradesh, India. Biology and Medicine Journal. 2012;4(2):73-9.

13. Deb T, Ray D. A Study of the bacteriological profile of chronic suppurative otitis media in Agartala. Indian Journal Otolaryngol Head Neck Surg. 2012;64(4):326-9.

14. Sulabh B, Tarun O, Suresh K, Amit S, Pratibha V. Changing microbiological trends in cases of chronic suppurative otitis media patients. International Journal of Current Research and Review. 2013;5(15):76-81.

15. Orji FT, Dike BO. Observatons on the current bacteriological profile of chronic suppuratve otitis media in South Eastern Nigeria. Annals of Medical and Health Sciences Research. 2015;5(2):124-8.

16. Nazir A, Kadri SM. Aerobic bacteriology of chronic suppurative otitis media: a hospital based study. International Journal of Research in Medical Sciences. Kashmir, India. 2014;2(4):1521-5.

17. Al-Hilli ZB. Study of bacterial isolates and their susceptibility pattern in chronic suppurative otitis media. Journal of Pharmacy and Biological Sciences, Iraq. 2015;10(6):1-5.

18. Ahmad S. Antibiotics in chronic suppurative otitis media: a bacteriologic study. Egyptian Journal of Ear, Nose, Throat and Allied Sciences. 2013; 14(3):191-4.

19. Poorey VK, Thakur P . Clinicomicrobiological evaluation and antibiotic susceptibility in cases of chronic suppurative otitis media. Indian Journal of Otology. 2015;21(2):107-10.

20. Wasihun AG, Zemene Y. Bacterial profile and antimicrobial susceptibility patterns of otitis media in Ayder. Springer Open Journal. Northen Ethiopia 2015;4(701):2-9. 